India // Palaeogeography, Palaeoclimatology, Palaeoecplpgy. 2003. Vol. 191. P. 1-14.

13. Arche A, Lopez-Gomez J. Sudden changes in fluvial style across the Permian-Triassic boundary in the eastern Iberian Ranges, Spain: Analysis of possible causes // Palaeogeography, Palaeoclimatology, Palaeoecology. 2005. Vol. 229. P. 104126.

14. Collinson J.W., Hammer W.R., Askin R.A., Elliot D.H. Permian-Triassic boundary in the central Transantarctic Mountains, Antarctica // Bull. of Geological Society of America. 2006. Vol. 118. P. 747-763.

15. Retallack G.J. Earliest Triassic claystone breccias and soil-erosion crisis // J. of Sedimentary Research. 2005. Vol. 75. P. 679-695.

16. Wignall P.B., Twitchett R.J. Oceanic anoxia and the end Permian mass extinction // Science. 1996. Vol. 272. P. 11551158.

17. Retallack G.J. Permian-Triassic life crisis on land // Science. 1995. Vol. 267. P. 77-80.

18. MacLeod K.G., Smith R.M.H., Koch P.L., Ward P.D. Timing of mammal-like reptile extinction across the PermianTriassic boundary in South Africa // Geology. 2000. Vol. 28, P. 227-230.

19. Tverdokhlebov V.P., Tverdokhlebova G.I., Benton M.J., Storrs G.W. First record of footprints of terrestrial vertebrates from the Upper Permian of the Cis-Urals, Russia // Palaeontology. 1997. Vol. 40. P. 157-166.

20. Губин Ю.М., Голубев В.К., Буланов В.В., Петухов С.В. Следы парейазавров из верхней перми Восточной Европы // Палеонтологический журн. 2003. Т. 37. С. 514-523.

21. Heyler D., Lessertisseur J. Pistes de tetrapodes Permiens de la region de Lodeve (Herault) // Memoire du Museum National d Histoire Naturelle, Paris. Serie C. Sciences de la Terre. 1963. Vol. 11. P. 125-221.

22. Tverdokhlebov V.P., Tverdokhlebova G.I., Minikh A.V. et al. Upper Permian vertebrates and their sedimentological context in the South Urals, Russia // Earth-Science Reviews. 2005. Vol. 69. P. 27-77.
23. Rubidge B.R. Biostratigraphy of the Beaufort Group (Karoo Supergroup) // Geological Survey of South Africa, Biostratigraphic Series. 1995. Vol. 1. P. 1-46.

24. Каландадзе Н.Н., Куркин А.А. Новый пермский дицинодонт и вопрос происхождения Kannemeyeroidea // Палеонтологический журнал. 2000. Т. 36. С. 642-649.

25. Kemp T.S. The origin and evolution of mammals. Oxford University Press, Oxford, 2005.

26. Surkov M.V., Benton M.J., Twitchett R.J.et al. The first occurrence of footprints of large therapsids from the Upper Permian of European Russia // Palaeontology. 2007. Vol. 50. P. 641-652.

27. Tverdokhlebov V.P., Tverdokhlebova G.I., Surkov M.V., Benton M.J. Tetrapod localities from the Triassic of SE of European Russia // Earth-Science Reviews. 2003. Vol. 60. P. 1-66.

28. Smith R.H.M., Botha J. The recovery of terrestrial vertebrate diversity in the South Africa Karoo Basin after the endPermian extinction // Comptes Rendus Palevol. 2005. Vol. 4. P. 623-636.

29. Surkov M.V., Kalandadze N.N., Benton M.J. Lystrosaurus georgi, a dicynodont from the Lower Triassic of Russia // J. of Vertebrate Paleontology. 2005. Vol. 25. P.402-413.

30. Battail B., Surkov M.V. Mammal-like reptiles from Russia / Eds. M. Benton, M. Shishkin, D. Unwin, E. Kurochkin. The age of Dinosaurus in Russia and Mongolia. Cambridge University Press, Cambridge, 2000. P. 86-119.

31. Grauvogel-Stamm L., Ash S.R. Recovery of the Triassic land flora from the end-Permian life crisis // Comptes Rendus Palevol. 2005. Vol. 4. P. 593-608.

32. Wignall P.B. Large igneous provinces and mass extinctions // Earth-Science Reviews. 2001. Vol. 53. P. 1-33.

33. Benton M.J., Twitchett R.J. How to kill (almost) all life: the end-Permian extinction event // Trends in Ecology and Evolution. 2004. Vol. 18. P. 358-365.

34. Corsetti E.A., Baud A., Marenco P.J., Richoz S. Summary of Early Triassic carbon isotope records // Comptes Rendus Palevol. 2005. Vol. 4. P. 405-418.

\title{
ПАЛЕОГЕОГРАФИЧЕСКАЯ ИНТЕРПРЕТАЦИЯ ТАФОНОМИИ ОСНОВНЫХ МЕСТОНАХОЖДЕНИЙ ИХТИОФАУНЫ СРЕДНЕЙ И ВЕРХНЕЙ ПЕРМИ ЕВРОПЕЙСКОЙ РОССИИ
}

\section{М.Г. Миних, А.В. Миних, Д.И. Янкевич 1 \\ Саратовский государственный университет, кафедра геоэкологии \\ E-mail: MinihMG@info.sgu.ru \\ 10тделение геологии НИИ ЕН СГУ}

Палеогеографические реконструкции обстановок осадконакопления в значительной мере детализированы тафономическими данными исследований местонахождений ихтиофауны, среди которых пермские рыбы Восточной Европы в последние годы приобрели статус ортостратиграфических. Проведенные тафономические исследования ряда местонахождений средне- и позднепермской ихтиофауны во многом подтверждают реальность существования в казанский, уржумский и северодвинский века на территории Европейской России довольно крупных бассейнов седиментации, имевших периодическую связь с Мировым океаном.

Ключевые слова: местонахождения ихтиофауны, средняя и верхняя пермь, европейская часть России, тафономия, палеогеографическая интерпретация. 
Paleogeographic Interpretation of the Taphonomy of the Principal Middle and Upper Permian Ichthyofauna Locations from European Russia

\section{M.G. Minikh, A.V. Minikh, D.I. Yankevich}

Paleogeographic reconstructions of sedimentation settings have been substantially refined from the taphonomic data from the ichthyofauna localities; the Permian fishes from East Europe have lately acquired the orthostratigraphic status. The taphonomic research in a number of the Middle and the Late Permian ichthyofauna locations has largely confirmed the reality of existence of fairly extensive sedimentation basins over European Russia in the Kazanian, the Urzhumian and the Severodvinian ages; those basins used to be periodically connected with the World Ocean.

Key words: localities of ichthyofauna, middle and upper Permian, European Russia, taphonomy, palaeogeographic interpretation.

Тафономические наблюдения с давних пор рассматриваются как необходимый компонент полноценных палеонтологических исследований [1-3], позволяющих реконструировать среду осадконакопления и процессы захоронения. Немаловажное значение в этом аспекте имеют исследования условий захоронения средне- и позднепермской ихтиофауны на территории Европейской России. На сохранность ископаемых организмов существенное влияние оказывают посмертные процессы, которые ограничивают частоту встречаемости их остатков или полностью исключают их из геологической летописи.

Костные остатки ископаемых рыб чаще всего представлены ихтиолитным материалом, включающим разрозненные кости и фрагменты черепных костей, зубы, зубные пластинки и кости посткраниального скелета (чешуи, лепидотрихии плавников, фулькры, плавниковые шипы). Значительно реже в ископаемом состоянии захороняются целые скелеты и сочлененные части скелетов рыб - головы, крупные фрагменты чешуйного покрова, плавники. Эти находки наиболее ценны для определения таксономической принадлежности и палеоэкологии рыб.

Цельноскелетные остатки рыб часто связаны с лагунами и подводными участками дельт, где темп осадконакопления наиболее высок, а существование бассейнов было устойчиво длительным, или с участками, где присутствуют явления сероводородного заражения придонных вод. Остатки рыб в виде изолированных ихтиолитов обычно рассеяны в бассейновых осадках в широком диапазоне подводных обстановок. Ранее исследованиями Н.Н. Верзилина с соавторами [4] и авторов настоящей статьи $[5,6]$ на примере песчаных линз была показана весьма значительная роль в бассейновом осадконакоплении процессов переноса и отложения терригенного материала в виде мутьевых и турбидитоподобных потоков, отложений баров и береговых валов. Часто в разрезе они представлены в виде линзообразных тел и долго маскировались под «аллювиальные русла».
В типично континентальных условиях осадконакопления остатки рыб более редки и фрагментарны. Однако и здесь присутствуют благоприятные условия для сохранения скелетов рыб, обычно связанные с захоронением в речных старицах и озёрах.

Проведенные исследования позволяют более чётко охарактеризовать выделенные ранее авторами [5] тафономические типы захоронений рыб, которые были сгруппированы М.Г. Минихом [6] в два ряда - бассейновый и континентальный. При этом под бассейновым рядом тафономических типов понимались достаточно крупные водоёмы морского и полуморского типа, лагуны, эпиконтинентальные или шельфовые моря как с нормальной соленостью, так и засолонённые или распресненные. Под континентальным рядом тафономических типов понимаются захоронения в реках, старицах, озерах. Тем не менее часто бывает трудно однозначно определить тип захоронения. Существует, как отмечал ещё В.Г. Очев [2] целая «гамма постепенных переходов», так как В действительности условия захоронения фауны многообразны.

В настоящей публикации достаточно полно будут рассмотрены шесть (из 10, выделенных М.Г. Минихом в 1992 году) наиболее значимых для палеогеографии типов захоронений рыб в восточноевропейских местонахождениях среднеи позднепермского возраста. Это известняковоалевритовый тафономический тип среднего шельфа, песчано-карбонатный тафономический тип баров и береговых валов, песчано-глинистоалевритовый тафономический тип мутьевых потоков на мелком и среднем шельфе, карбонатноглинисто-алевритовый тафономический тип прибрежного мелководья или мелководного шельфа, карбонатно-глинистый тафономический тип заливов и лагун и песчано-алеврито-гравийный тафономический тип турбидитоподобных гравитационных потоков на шельфе.

Захоронение известняково-алевритового тафономического типа среднего шельфа наблюдалось нами в отложениях казанского яруса средней перми на правом берегу реки Пинега в Архангельской области в местонахождениях Курга-1, -2, Нельнюга-1, -2, -3, Шилега-1 и других [7]. Здесь в известковых алевролитах, известковистых песчаниках, а также в небольшой песчано-алевритовой линзе, залегающей среди биогермов, насыщенных разнообразными морскими ископаемыми беспозвоночными - мшанками, брахиоподами, криноидеями и другими группами животных, встречаются многочисленные фрагментарные остатки хрящевых рыб (зубы и ихтиодорулиты акуловых, зубные пластинки субтербранхиалий), а также разрозненные кости и чешуи лучеперых рыб. Костные остатки рассеяны по всему слою неравномерно.

Для песчано-карбонатного тафономического типа баров и береговых валов характерны хорошая сортировка и линзообразное залегание 
преимущественно терригенных и карбонатных вмещающих кости пород и фрагментарность остатков наземных позвоночных и рыб. Фрагментарный ихтиолитный материал в больших концентрациях, вплоть до образования костных брекчий, встречается в прибрежно-морских отложениях казанского возраста. В качестве примера можно привести открытое и изученное в тафономическом плане М.Г. Минихом в 1971 году местонахождение Усть-Коин казанского возраста средней перми. Оно расположено на р. Вымь, в бассейне р. Вычегда в Республике Коми. Многочисленные чешуи, ихтиодорулиты, зубы, покровные кости черепа и другие кости скелета рыб захоронены совместно с обугленными обломками стволиков и веток палеорастений. Кости черного цвета захоронены в очень крепких, звенящих при раскалывании, известковых песчаниках, образуя костную брекчию. Слой этот представляет собой линзу валикоподобной формы, мощностью до 0,4 м и шириной до 2,5 м, но достаточно большой протяженности, превышающей 300 м. Судя по вещественному составу, значительной протяженности и линзообразному залеганию костеносного слоя небольшой мощности в морских [8] известняках, содержащих фауну беспозвоночных, генезис местонахождения связывается с образованием берегового вала. Подобные скопления фрагментарного ракушечного и костного материала, включая остатки рыб, наблюдались нами и в местонахождениях триасового возраста в Московской синеклизе, а также по берегам современных Каспийского и Аральского морей.

В разрезах средней и верхней перми среди горизонтально наслоенных глинисто-карбонатных пород хорошо заметны инородные по составу и текстурным признакам песчано-глинисто-алевритовые линзы различной формы. Для них характерны эрозионный врез, чёткие латеральные границы и переслаивание в кровле, градационная слоистость внутри. Возможна многоактность осадочного процесса в одной линзе по мере заполнения каньона в дне бассейна. Остатки раковин беспозвоночных и ихтиолиты в таких линзах нередко имеют беспорядочную ориентировку, фрагментарны и деформированы; реже встречаются цельноскелетные остатки рыб, особенно в кровле или подошве линз. Такое захоронение отнесено к песчано-глинистоалевритовому тафономическому типу мутьевых потоков на мелком и среднем шельфе.

Примером этого тафономического типа является местонахождение Мутовино на правом берегу р. Сухона, напротив д. Нижние Исады в Вологодской области. Линза врезана в прекрасно обнаженные отложения полдарсской свиты северодвинского яруса верхнего отдела перми, насыщенные многочисленными палеонтологическими остатками - остракодами, двустворчатыми моллюсками, конхостраками, тетраподами, рыбами, отпечатками листовой флоры и харовыми водорослями. Свита характеризуется распространением карбонатно-терригенных образований мощностью около 90 м, простирающихся на несколько сотен километров [9]. Структурные и текстурные особенности этих пород, по данным 3.А. Яночкиной и Т.Ф. Букиной [10], «позволяют предположить, что накопление их происходило как в относительно глубоководных, так и мелководных зонах бассейна, значительно удаленных от устьевых частей рек. Поступление терригенного материала было незначительным. Полиморфный кальцит мог накапливаться, как в результате хемогенной садки, так и приноситься в виде терригенной мути реками» [10, с. 150]. Осадконакопление, по данным Н.Н. Верзилина с соавторами [4], происходило здесь в обстановке устойчиво существовавшего обширного лагунного водоема; отмечается, что в разрезе нет следов перерывов, а также следов влияния на осадконакопление деятельности штормов. Эти данные согласуются и с нашими представлениями, за исключением понятия «лагунные», так как трудно назвать лагуной обширный эпиконтинентальный бассейн (Полдарсское море), протяженность которого была не менее многих сотен километров.

Максимальная мощность Мутовинской линзы около 18 м, протяженность (по нашим последним замерам в 2001 г.) - 300 м. Линза имеет резко асимметричное строение и четкую эрозионную границу с подстилающими породами. Её слагают неотсортированные песчаники, алевролиты, аргиллиты, глины, карбонатные породы; есть прослои гравелитов и конгломератов. Конгломераты зеленовато-серые, мелкогалечные (диаметром до $1 \mathrm{~cm})$, состоящие из плохо окатанных глинистых галек и известняков. Они залегают в линзе на разных уровнях; в них отмечено присутствие обильных углистых включений, раздавленных раковин двустворок, в разной степени деформированных разрозненных костей тетрапод, чешуи и костей рыб, многочисленных остракод. Песчаники и алевролиты зеленовато-серые, полимиктовые, известковистые, тонкозернистые; содержат редкие кости тетрапод и остракод. Аргиллиты желто-серые, прослоями почти черные. В них присутствуют многочисленные остракоды, кости рыб и тетрапод; есть раковины двустворчатых моллюсков и отпечатки листовой флоры. Глины известковистые, микрослоистые. Пока только в базальных слоях линзы обнаружены скелет и редкие фрагменты рыб Isadia suchonensis A. Minich и Strelnia certa A. Minich. Остальные остатки рыб представлены неравномерно распределенными в толще линзы разрозненными частями скелета (чешуями и зубами) лучеперых рыб: Toyemia tverdochlebovi Minich, Strelnia certa A. Minich, Mutovinia stella Minich и Geryonichthys longus A. Minich. Такая средней степени сохранность костей характерна для отложений мутьевых потоков в удаленных от берега субаквальных частях дельт.

Подобная интерпретация генезиса Мутовинской линзы подтверждается независимыми литолого-минералогическими исследованиями 
Н.Н. Верзилина с коллегами [4], которые подчеркивают, что линза образовалась в субаквальной обстановке. Это следует, по их мнению, из тонкозернисто-псевдоколлоидального микростроения карбонатного и глинистого материала самой линзы и вмещающих ее пород и рассматривается как показатель отсутствия осушения осадков. Согласно их заключению, которое мы поддерживаем, на месте линзы существовал пониженный рельеф дна, куда поставлялся и достаточно быстро откладывался в водных условиях осадочный материал.

Подробное описание трех последних тафономических типов местонахождений как наиболее представительных и полнее тафономически изученных приводится ниже на примере местонахождения Кичкас.

Среднепермское местонахождение Кичкас расположено в бассейне р. Большой Уран в Оренбургской области. Тафономия этого местонахождения изучалась после его открытия в 1984 году М.Г. Минихом и А.В. Миних и в течение последующих четырех лет. Одноразовое посещение местонахождения с отбором специальных образцов было проведено А.В. Гоманьковым (флористические остатки), И.И. Молостовской (остракоды) и Т.И. Погуцей (минералогические исследования). В настоящей работе этому местонахождению отводится самое большое внимание в связи с его насыщенностью скелетами различных групп рыб.

Оно является одним из уникальнейших местонахождений в России по обилию, разнообразию и сохранности пермских рыб в сочетании с остатками листовой флоры, кокколитофорид, остракод, двустворчатых моллюсков и фрагментарными остатками тетрапод [11]. Подобная ассоциация ископаемых органических остатков в одном местонахождении представляет немалый интерес в изучении его тафономической природы. Параллельно здесь были проведены минералогогеохимические и петрографические исследования пород, вмещающих ископаемую органику. Разрез состоит преимущественно из сероцветных карбонатных пород с редкими прослоями песчано-алевритовых разностей. Его мощность не превышает 6 м. В геологическом отношении (основываясь на определении И.И. Молостовской остракод - Paleodarwinula fragiliformes, P. elongata, P. torensis, P. inornatinae, $P$. arida, Prasuchonella nasalis) разрез, включающий ископаемую ихтиофауну, представлен отложениями аманакской свиты в верхней части наиболее полных разрезов уржумского яруса.

Тафономические наблюдения костеносной части разреза осуществлялись в процессе планомерных раскопок сверху вниз, однако подробное послойное описание разреза, без которого нельзя обойтись при изучении условий захоронения ископаемых органических остатков, приводится снизу вверх:
1. Пачка переслаивания глинистых известняков светло-зеленовато-серых, рыхлых, участками плотных, тонкоплитчатых, с алевритистыми песчаниками, песчанистыми алевролитами на кальцитовом цементе (мощностью до 5 см) и с редкими прослоями ракушечников мощностью до 20 см. Породы содержат обильную вкрапленность карбоната меди, за счет чего выделяются в разрезе зеленоцветностью. В слое встречаются обугленные стволы деревьев диаметром до $15 \mathrm{~cm}$, состоящие из известково-песчанистых алевролитов и ориентированные на север и северо-восток. Часто встречаются остатки костей тетрапод разной степени окатанности, а также черные и коричневые чешуи и кости (редко скелеты) рыб разной степени сохранности. Слой насыщен раковинами остракод неплохой сохранности, а также раковинами двустворчатых моллюсков как из целых раковин (редко), так и из разрозненных створок, часто раздавленных, размером 1-5 см. B.M. $-1,8 \mathrm{M}$.

2. Известняки светло-голубовато-серые, кокколитовые, плотные, крепкие, с редкими отпечатками листовой флоры желтовато-коричневого цвета, с редкими фрагментами скелетов рыб и еще реже - с их целыми скелетами и с объемными раковинами двустворчатых моллюсков. По простиранию плотные разности известняков часто сменяются глинистыми известняками, мягкими во влажном состоянии и так же состоящими из кокколитов - известковых пластинок планктонных микроорганизмов размером около 10 мкм. Состав известняков из кокколитов в данном местонахождении впервые обнаружила Т.Ф. Букина в процессе изучения шлифов в 1986 году. Глинистые известняки имеют светло-серо-фиолетовый цвет и содержат ту же ископаемую органику, что и плотные известняки, но в большем количестве. К кровле слоя приурочены горизонтально лежащие единичные остатки стволов палеодеревьев, диаметром до 8 см, ориентированные на северо-восток. По всему слою рассеяны раковины остракод. M. $-0,2$ M.

3. Известняки-ракушечники ржаво-желтые и желто-коричневые, с охристыми присыпками и корочками, глинистые и алевритистые, с волнисто-плитчатой отдельностью, средней плотности внутри плиток и рыхлые к краям. Состоят из сплюснутых раковин двустворчатых моллюсков разных размеров. Между раковинами много ярко-желтых мучнисто-рыхлых образований неправильной формы размером до 3 см, похожих на копролиты. Известняки содержат прослои (мощностью до $1 \mathrm{~cm}$ ) светло-серых алевролитов. В породах часто встречаются крупные (до 20 см) ихтиодорулиты акуловых рыб хорошей сохранности, неокатанные, но не всегда целые, а также разрозненные кости и чешуи различных групп лучеперых рыб разной степени сохранности. Присутствуют остракоды и редкие, преимущественно окатанные, обломки костей тетрапод (позвонки, 
зубы, кости плечевого пояса). Встречаются обугленные обломки древесины, крупные округлые семена и отпечатки листьев. Ракушечники не выдержаны по мощности, нередко расслаиваются на тонкие пропластки, между которыми залегают алевро-глинистые или глинисто-известковые породы мощностью до $10 \mathrm{~cm}$.

По простиранию ракушечники замещаются серовато-фиолетовыми, с желтыми пятнами и разводами, глинистыми кокколитовыми известняками, содержащими раковины двустворчатых моллюсков и остракод, фрагменты костей рыб и отпечатки флоры. Породы содержат пропластки из крупных округлых конкреций плотных и крепких известняков, иногда окремнелых внутри и преимущественно состоящих из чистого кальцита. M. $-0,75$ м.

4. Известняки глинистые, внизу серофиолетовые (2-4 см), выше - светло-серые и светло-коричневые, кокколитовые, средней плотности, мягкие, участками крепкие и очень плотные. Породы насыщены разнообразной фауной. К верхней части слоя приурочены многочисленные скелеты рыб и их фрагменты. Размеры рыб колеблются от 5-7 до 70 см. Здесь найдены части скелетов акул, скелеты различных родов и видов рыб из отряда Eurynotoidiformes, высокотелые - Kargalichthys и Platysomus, масса рыб рода Varialepis, несколько скелетов Samarichthys и один скелет Discordichthys. Некоторые скелеты рыб изогнуты так, что хвост повернут в сторону головы. На единичных скелетах чешуйный покров содержит следы механического или химического воздействия - выбоинки и осветленные части на черном фоне. Наиболее целые скелеты приурочены к плотным разностям микрослоистых известняков. По всему слою встречаются остракоды и раковины двустворчатых моллюсков прекрасной сохранности. В нижней части слоя много отпечатков листьев, семян и веточек растений. М. $-0,12$ м.

5. Известняки-ракушечники светло-серожелтые, состоящие из раковин двустворок; встречаются чешуи различных групп рыб, преимущественно высокотелых, есть копролиты и редкие окатанные кости тетрапод. М. - 0,12 м.

6. Известняки глинистые кокколитовые, участками алевритистые или песчанистые, розовато-фиолетово-серые и коричневатосветло-серые, мягкие, участками плотные. Coдержат многочисленные скелеты рыб различной систематической принадлежности (Kargalichthys efremovi, Platysomus biarmicus, Lapkosubia uranensis, L. barbalepis, Kichkassia furcae, Samarichthys luxus, Varialepis bergi и еще не изученные акуловые), которые лежат в слое на 2, 3 уровнях, иногда соприкасаясь друг с другом. Найден скелет крупного высокотелого платисомуса, на котором лежит небольшая рыбка-лапкозуб. Чаще рыбки раздавлены латерально, иногда - сверху вниз. Большинство рыб вытянуто в струнку, очень и очень редко - изогнуты (хвост к голове). Некоторые части скелета бывают слегка смещены относительно друг друга. Сохранность скелетов рыб в основном очень хорошая. Скопление скелетов значительно: примерно на 1 м $^{2}$ площади костеносного слоя приходится до 20 скелетов рыб, длина которых колеблется от 7 до 30 см. Какая-либо упорядоченность в ориентировке отсутствует (рисунок).

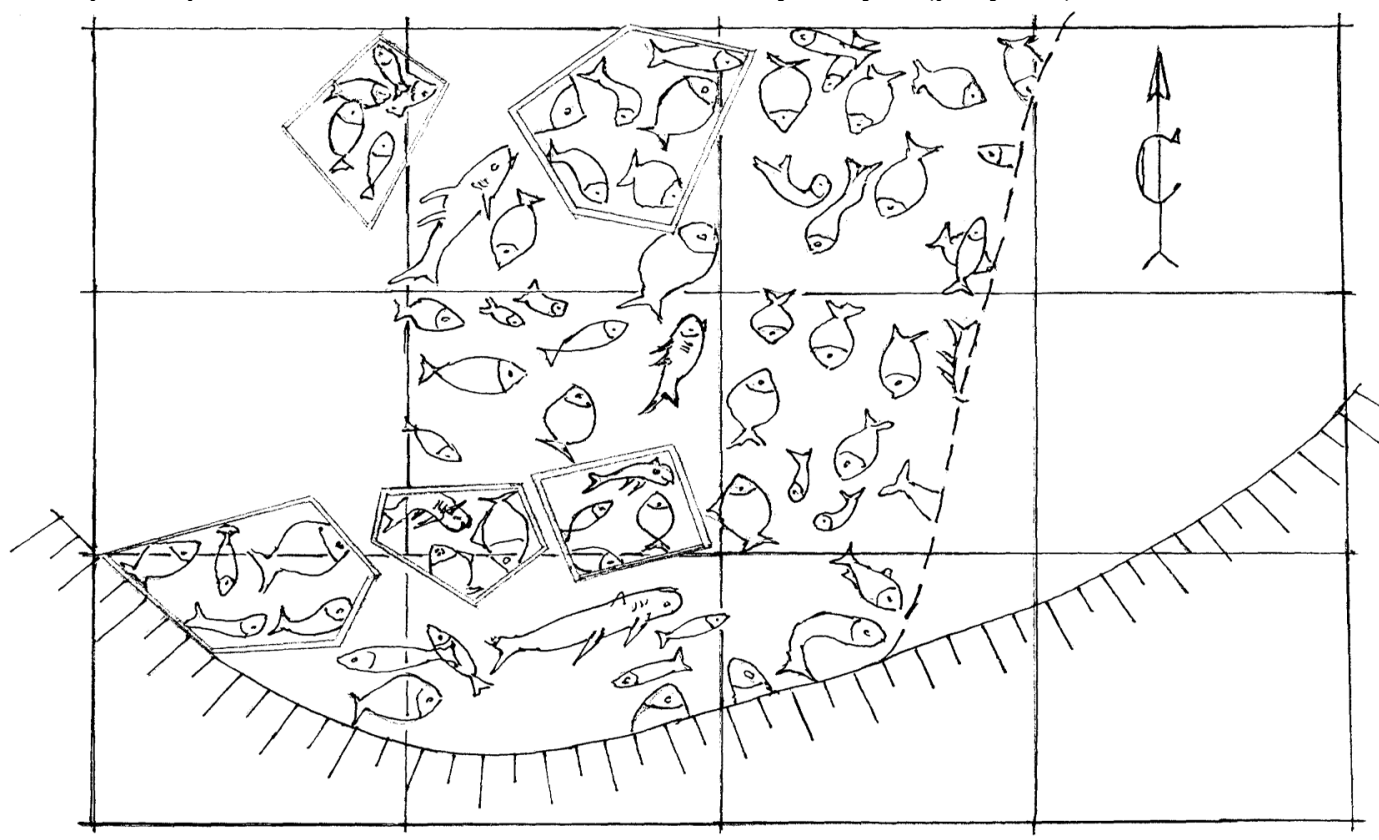

Схематический план раскопки костеносного слоя № 6 в местонахождении Кичкас, выполненный по технологии палеонтологического квадрата со стороной в 100 см. Рыбы были взяты с применением стандартной методики «гипсовый пирог» и «монолит»:пунктир - линия постдиагенетического размыва костеносного пласта 
Встречаются отдельные черепа рыб, сочлененные кости плечевого пояса, плавники. Есть объемные части скелета голов (в более плотных разностях известняков). Уникальны по своей сохранности находки остатков акул с хорошо сохранившимся дермальным покровом из мелких плакоидных зубоподобных чешуек и плавниковыми шипами в естественном положении; сохранился даже хрящевой скелет головы. В слое есть остракоды, двустворки, отпечатки листовой флоры. Раковины остракод и моллюсков захоронены большей частью с замкнутыми створками равномерно-рассеянно по всему слою. Остракоды величиной до 1 мм, не скульптированы, створки из тонковолокнистого кальцита, цвет либо аналогичный цвету породы, либо иной, но чаще светло-коричневый. Последнее позволяет предположить, что наряду с аллохтонным захоронением остракод имело место автохтонное. Захоронение моллюсков, размеры которых колеблются от 0,5 до 4 см, было преимущественно in situ - они ориентированы макушками вверх, перпендикулярно плоскости напластования пород, что свидетельствует о достаточно быстром темпе их захоронения.

Листья и семена растений хорошей сохранности, на листьях сохранились прожилки. Присутствуют длинные и тонкие отпечатки водорослей. Среди флоры А.В. Гоманьковым [11] определены птеридоспермы Odontopteris rossica Zalessky, папоротники Fefilopteris cf. pilosa Gomankov, побеги хвойных растений Geinitzia sp., дисперсные синангии Permotheca sardykense Zalessky, семена Carpolites sp., по одному экземпляру женских фруктификаций Lopadiangium sp. и Krylovia sp. M. $-0,06$ м.

7. Линзовидное переслаивание фиолетовых и зеленовато-серых глинистых известняков с желто-серыми ракушняками и зеленовато-серыми алевритами. Слой содержит разрозненные окатанные и полураздавленные кости тетрапод светлокоричневого цвета и кости рыб черного цвета хорошей сохранности; много раковин двустворчатых моллюсков и остракод отличной сохранности, особенно в фиолетовых разностях пород.

Биостратономические особенности захоронения моллюсков определялись посредством палеонтологического квадрата. Раковины не имеют упорядоченной ориентировки, их размер колеблется от 2 до 5 см, но преимущественно составляет 3-4 см. На $1 \mathrm{~m}^{2}$ площади слоя приходится 2500-3000 раковин моллюсков. М. - 0,2 м.

8. Известняки-ракушняки желто-серые, плитчатые, в подошве очень крепкие. Они на 90-95\% сложены раковинами двустворок, выполненными среднекристаллическим и тонковолокнистым кальцитом; цемент из серого пелитоморфного кальцита. Раковины расположены безсистемно, плотно, в большинстве - смяты. Встречаются обугленные стволики растений диаметром до 5 см. Много хорошей сохранности чешуй рыб: платисомусов, каргалихтисов, вариалеписов, уранихтисов (редко) и стрелний (редко). В подошве слоя иногда встречаются небольшие (5-10 см в длину) скелеты рыб эуринотоидиид. Очень редки раздавленные обломки костей тетрапод. М. - 0,4 м.

9. Известняки глинистые, светло-серые, вверху кальцитовые, чистые, плотные, состоящие из зерен пелитоморфного кальцита и представляющие собой фрагменты кокколитофорид, с тонкими (до 5 мм) пропластками желтых алевритов. В слое встречаются редкие раковины двустворок хорошей сохранности, копролиты и чешуи, а также единичные скелеты рыб, отпечатки листовой флоры и обугленные кусочки древесины. Редкие разрозненные чешуи лучеперых рыб (и очень редко скелеты) встречаются в верхнем прослое известняков. Чешуи и скелеты рыб темно-коричневые, захоронены параллельно плоскости напластования пород. Есть копролиты. Присутствуют редкие веточки, плоды и отпечатки листьев растений хорошей сохранности, выполненные ржаво-желтым алевритом, а также небольшие раковины двустворчатых моллюсков с сомкнутыми створками и с сохранившимся раковинным веществом, чаще захороненные в прижизненном состоянии макушками вверх. От некоторых раковин двустворок проходят бороздки, заполненные более рыхлым материалом; это, возможно, следы передвижения моллюсков. Иногда попадаются раскрытые створки, некоторые раковины лежат на боку. Присутствуют разновозрастные особи моллюсков. Раковины без всяких следов прижизненного повреждения и неокатанные. В подошве, кроме раковин хорошей сохранности, присутствуют многочисленные ядра этих моллюсков. Остракоды хорошей сохранности, их створки выполнены тонковолокнистым кальцитом. М. - от 0,1 до 0,2 м.

Выше с размывом залегают песчаные разности пород, срезая известняки с востока на большую глубину под углом до $35^{\circ}$. Северная стенка известняков отвесно срезана песчаниками так, что в известняках сохранилась лишь половинка скелета рыбы.

Песчаники грязно-сиреневые, серо-зеленые и ржаво-коричневые, кварцево-известковые, тонкозернистые, горизонтально-слоистые и косослоистые с обугленным детритом и отпечатками растений, с редкими раковинами двустворчатых моллюсков и остракодами. Песчаники плохо отсортированы, зерна хорошо окатаны. Видимая мощность пород в раскопке около 1,4 м.

По простиранию в восточном направлении наблюдается значительное увеличение мощности этих же песчаных напластований (до 16 м), хорошо обнаженных в стенке близлежащего оврага, удаленного от раскопки кичкасского местонахождения на 120-150 м. Здесь песчаники часто замещаются песками и представляют собой толщу косонаслоенных пачек, выполняющих понижение в палеорельефе дна бассейна седиментации. В нижней части пачки песков и песчаников 
присутствует линза конгломератов мощностью 3,5 м, светло-красновато-коричневых, с хорошо выраженными крупными косыми сериями до 1,2 м мощностью. Гальки и гравий состоят из мергелей, известняков, глин и (реже) песчаников. В песках присутствуют обломки стволиков палеорастений диаметром около 2 см; в средней части слоя найдены редкие чешуйки рыб и раковины двустворок. Перекрывается песчаная толща пластом известняков, видимой мощностью 0,12 м. Известняки глинистые, светло- и темно-серые, плотные, крепкие, звенящие при расколе; содержат очень тонкие линзообразные прослои пелитоморфного кальцита и ржаво-желтых глинистых алевролитов. Известняки по составу сближаются с аналогичными в слое 9 в раскопе местонахождения Кичкас. В них встречены многочисленные раковины остракод и двустворчатых моллюсков очень хорошей сохранности (выпуклые, с замкнутыми створками) и ихтиолиты платисомид и эуринотоидиид. Все это дает основание предполагать субсинхронность формирования костеносных известняков и мощной толщи песчаников. С учетом явной эрозионности вреза песчаников они сформировались в понижении рельефа дна бассейна в виде турбидитоподобного потока обводненных масс, соскользнувших из прибрежных участков в результате превышения критических углов наклона дна в процессе накопления принесенного рекой с суши аллювиального песчаного материала. Очевидно, что накопление достаточно мощных косонаслоенных песчаных масс образовалось за значительно более короткое время, чем формировались соседние карбонатные осадки костеносной части местонахождения Кичкас. Этот тип захоронения резко отличается от вышеописанных в данном местонахождении и может быть отнесен к песчано-алеврито-гравийному тафономическому типу турбидитоподобных гравитационных потоков на шельфе.

Из приведенного выше разреза местонахождения Кичкас (непосредственно в раскопке) видно, что состав пород, вмещающих остатки рыб, неоднороден. Преимущественно это чистые и глинистые известняки, ракушняки и смешанные глинисто-песчано-карбонатные разности. Составной частью вещества известняков и глинистых известняков, по данным Т.И. Погуцы [11], являются кокколитофориды, типично морские организмы с известковым скелетом. Их присутствие свидетельствует о существовании связи бассейна осадконакопления с открытым морем. Подтверждением тому служит повышенное содержание стронция, концентрация которого, по данным C.M. Катченкова [11], увеличивается в морях за счет сорбционного поглощения глинистыми частицами и биогенного накопления, так как организмы извлекают стронций из раствора, а после гибели обогащают им осадки. Нами для выяснения условий седиментации использован стронций-бариевый коэффициент. По 25 образцам из всех литологических разностей вмещающих кости рыб пород полуколичественным спектральным анализом установлено превышение стронция над барием в 2-4 раза, а в отдельных образцах и более в связи с полным отсутствием бария. Последнее объясняется быстрым выходом бария из путей миграции при попадании в морские воды. Кроме того, в известняках велико содержание марганца (до 1000×10-8\%), который, как показывает C.М. Катченков [11], мигрирует дальше других элементов группы железа в морских водоемах и накапливается в карбонатных и карбонатнотерригенных осадках. Максимальное количество растворенного железа (от 80 до 95\%) выпадает, по данным А.П. Лисицына [12], в устьях рек на границе река-море. Среди микроэлементов в нижней части разреза ураганных концентраций достигает медь (медистые песчаники).

Песчаники и пески, срезающие и перекрывающие костеносные отложения, неоднородны по составу, окраске и текстурным особенностям. В их составе преобладают хорошо окатанные, среднесортированные зерна кварцево-кремнистого (до $50 \%$ ) и известкового (до 30\%) состава, много гидрослюд (5-15\%), полевых шпатов (5-15\%), есть цеолиты (до 3\%). Состав песчаных зерен, их сортировка, степень окатанности и величина свидетельствуют о том, что песчаный материал поступал большей частью из относительно удаленных площадей, треть обломков - результат перемыва местных пород [11].

Суммируя вышеизложенные наблюдения по захороненным органическим остаткам в местонахождении Кичкас, можно сделать выводы об условиях их захоронения. Характер находок остатков рыб в известняках и глинистых известняках (слои $2,4,6,9)$ указывает на то, что захоронение происходило достаточно быстро, в бассейне обитания типа лагуны, в спокойной гидродинамической обстановке. Свидетельство тому - хорошая сохранность скелетов лучеперых рыб, а также акул, обладающих хрящевым скелетом, для захоронения которого требовались особые условия. Известно, что в случае длительного переноса трупов рыб к месту захоронения головы отделяются от туловища и захороняются раньше [13]. Глубина бассейна была не настолько мелководна, чтобы волны, поднимаемые ветром, могли воздействовать на тела погибших рыб. Имели место небольшие донные течения, о чем свидетельствуют изогнутость некоторых скелетов, разобщенность отдельных их частей до 1,5-2 см. Кроме того, в шестом слое была выявлена одновременная гибель разновозрастных представителей наиболее распространенных таксонов - Platysomus biarmicus, а также Lapkosubia uranensis, L. barbalepis и Kichkassia furcae. Одновременное попадание их в геологическую летопись стало возможным, вероятно, благодаря быстрому развитию заморного явления и практически мгновенной гибели фауны. Многочисленность рыб [14] характерна 
для участков водоема с относительно высокой концентрацией водных растений. Однако перенасыщения растениями не было, так как гниение их привело бы к избыточному содержанию $\mathrm{CO}_{2}$, что могло привести к прижизненному растворению раковин беспозвоночных [3]. Массовая гибель рыб была связана с резкими изменениями обстановки их обитания, возможно, с периодическими поступлениями сероводорода. События быстрого погребения целых биоценозов, связанные с массовой смертью, хорошо известны в науке $[13,15]$. Вероятно, близкие условия захоронения скелетов ихтиофауны могли существовать и во время накопления одного из слоев в верхней части третьей свиты уржумского яруса [16] в Монастырском овраге, расположенном на правом берегу р. Волги в 12 км севернее г. Тетюши в Татарстане. Здесь, в голубовато-серых глинистых известняках слоя 234 [16] также достаточно многочисленны скелеты платисомусов и лапкозубий, есть массовые скопления конхострак, встречаются остракоды и двустворчатые моллюски.

Относительно хорошая сохранность фрагментов береговой палеорастительности в местонахождении Кичкас дает основание предполагать незначительность ее переноса. Хорошая сохранность остракод, их равномерное распределение в известняках и глинистых известняках указывают, по мнению Г.И. Кармишиной, изучавшей в 1975 году плиоценовых остракод на юге европейской части России, на умеренную подвижность вод, а относительно большая толщина их стенок свидетельствует о сравнительной мелководности палеоводоема.

Представленные выше условия захоронения могут быть отнесены к карбонатно-глинистому тафономическому типу заливов и лагун.

Захоронения рыб в известняках-ракушняках отличались от вышеприведенных. В них практически не захоронены целые скелеты рыб и более-менее целые фрагменты растений. Можно предположить, что спокойная жизнь в водоеме нарушалась штормами, достигавшими дна лагуны в наиболее мелководных зонах. В эти периоды в западины дна сносились многочисленные раковины погибших двустворчатых моллюсков, части скелетов рыб в виде чешуй, фрагментов скелета головы, плавников, ихтиодорулитов. Не исключено, что штормы сопровождались сильными ливнями, которые способствовали переносу в бассейн реками и плювиальными потоками окатанных костей тетрапод и обломков древесины. Кроме того, трупы рыб выносились волнами и в прибрежную зону, где измельчались волнами и захоронялись совместно с раковинами двустворчатых моллюсков и костями тетрапод. Такое захоронение рыб в известнякахракушняках (в слоях $1,3,5,7,8)$ можно отнести к карбонатно-глинисто-алевритовому типу прибрежного мелководья или мелкого шельфа. К этому же тафономическому типу мы относим захоронение рыб в морских отложениях казанского яруса на правом берегу р. Пинега, вблизи устья р. Ежуга, в Архангельской области. Здесь, в тонких прослоях известняков-ракушняков, залегающих среди алевролитов и глин, насыщенных морской фауной беспозвоночных - брахиоподами, двустворчатыми моллюсками, остракодами, нами были обнаружены костные остатки рыб [7]. Среди них присутствуют рассеянные в породе зубы акул "Ctenacanthus» kurgaensis A. Minich, "Ct.» sp., Pinegocaptus rosanovi A. Minich, крупные ихтиодорулиты акул неясной систематической принадлежности и редкие чешуи лучеперых рыб. В казанских разрезах на р. Пинега есть и другие типы захоронений рыб. Два из них - захоронение в относительно глубоководных осадках и захоронение в рифогенных образованиях - описаны в работе [5] и здесь не упоминаются.

Представляется следующая картина палеогеографической обстановки в окрестностях местонахождения Кичкас. К концу уржумского времени здесь находилась окраина обширного и достаточно долго живущего эпиконтинентального бассейна с заливами, лагунами и эстуариями. Судя по таксономическому составу ихтиофауны и породообразующим кокколитовым водорослям, бассейн периодически имел связь с открытым морем. Проявление процесса распреснения наблюдается в нижней части изученного разреза, образование которого связывается с отложениями в подводной (субаквальной) части обширной дельты. Здесь периодически шло накопление несортированного и среднесортированного мелко- и среднезернистого песка, ракушечника, в которых захоронялись обломки привнесенных рекой костей тетрапод, чешуи и кости рыб, двустворки, обломанные стволики древесины. При наступлении более спокойного гидродинамического режима шло накопление алевритов, известкового ила с редкими скелетами рыб (вероятно, в захоронении in situ), двустворчатых моллюсков и остракод. С течением времени в зависимости от условий осадконакопления в этой части бассейна происходило накопление либо известковых илов, либо ракушняков, образующих так называемые «ракушняковые мостовые». Последние могли образовываться при активной гидродинамике вод при сильных волнениях в зоне влияния штормов. При возобновлении периодической связи с открытым морем происходило увеличение глубины бассейна, и в донных его осадках доминировал известковый (кокколитовый) ил. Достаточно часто здесь на отдельных участках фиксируется наступления аноксидных (скорее всего, сероводородных) заморных явлений, при которых погибали и попадали в захоронение многие водные обитатели отравленной зоны, в том числе разнообразная и разновозрастная (в онтогенезе) ихтиофауна, образуя довольно выдержанные костеносные слои (см. рисунок - схематический план вскрытия 6-го слоя кичкасского местонахождения рыб в Оренбургской области). 
Анализ представленных здесь тафономических типов местонахождений водных позвоночных показывает, что в казанский, уржумский и северодвинский века на территории Европейской России существенное значение имели условия седиментации в обширных эпиконтинентальных бассейнах, имевших периодическую связь с Мировым океаном как на юге, так и на севере изученного региона.

Таким образом, проведенные комплексные исследования палеонтологических, тафономических, литолого-минералогических и геохимических данных по ряду наиболее характерных местонахождений пермской ихтиофауны позволяют выявить бассейновые условия захоронения ископаемых рыб и с достаточной степенью достоверности реконструировать палеогеографию определенных участков земной поверхности Восточно-Европейской платформы в конце пермского периода.

Работа выполнена при финансовой поддержке РФФИ (грант 07-05-00624).

\section{Библиографический список}

1. Ефремов И.А. Тафономия - новая отрасль палеонтологии // Изв. АН СССР. Сер. биолог. 1940. № 3. C. 405-413.

2. Очев В.Г. К вопросу о классификации местонахождений ископаемых наземных позвоночных // Вопросы геологии Южного Урала и Поволжья. 1967. Вып. 3, № 1. C. $205-216$.

3. Янин Б.Т. Основы тафономии. М., 1983. 184 с.

4. Верзилин Н.Н., Калмыкова Н.А., Суслов Г.А. Крупные песчаные линзы в верхнепермских отложениях севера Московской синеклизы // Тр. Санкт-Петербургского общества естествоиспытателей. 1993. Т. 83, вып. 2. 112 с.
5. Миних М.Г., Миних А.В. Особенности захоронения позднепермских и триасовых рыб // Теория и опыт тафономии. Межвуз. науч. сб. / Под ред. Г.В. Кулёвой и В.Г. Очева. Саратов, 1989. С. 82-91.

6. Миних М.Г. Значение тафономических исследований местонахождений рыб при интерпретации генезиса позднепермских и триасовых отложений // Материалы по методам тафономических исследований / Под ред. Г.В. Кулевой и В.Г. Очева. Саратов, 1992. С. 96-108.

7. Миних A.B. Новые виды акул рода Ctenacanthus Ag. из казанского яруса верхней перми бассейна реки Пинеги // Тр. Науч.-исслед. ин-та геол. Сарат. гос. ун-та. Новая сер. Саратов, 1999. Т. 1. С. 133-136.

8. Мальиева Е.О., Беляев А.А., Митяков С.Н., Носков А.В. Два типа разреза казанских отложений в бассейне p. Вымь // Геология, геохимия, геофизика на рубеже XXXXI вв. Т. 1. Тектоника, стратиграфия, литология: Материалы 3-й Всерос. науч. конф., 23-25 апр., 2002 г., Сыктывкар. Сыктывкар, 2002. С. 75-77.

9. Татарские отложения реки Сухоны / Под общ. ред. Э.А. Молостовского и А.В. Миних. Саратов, 2001. 204 с.

10. Яночкина.З.А., Букина Т.Ф. Фациальная принадлежность и условия формирования толщ // Татарские отложения реки Сухоны / Под общ. ред. Э.А. Молостовского и А.В. Миних. Саратов, 2001.С. 146-154.

11. Материалы по методам тафономических исследований / Под ред. Г.В. Кулевой и В.Г. Очева. Саратов, 1992.

12. Лисииын А.П. Лавинная седиментация и перерывы в осадконакоплении в морях и океанах. М., 1988. 306 с.

13. Weigelt J. Ganoidfischleichen im Kupferschiefer und der Gegenwart // Palaeobiologica. 1928. № 1. Р. 323-356.

14. Никольский Г.В. Экология рыб. М., 1974. 367 с.

15. MÜller A.H. Lehrbuch der palaozoologie. Jena, 1976. $423 \mathrm{p}$.

16. Гусев А.К. Опорный разрез татарского яруса у с. Монастырское // Стратотипы и опорные разрезы верхней перми Поволжья и Прикамья. Казань, 1998. С. 123-139.

\section{СОСТОЯНИЕ ИЗУЧЕННОСТИ ОВРАЖНОЙ ЭРОЗИИ} НА ТЕРРИТОРИИ САРАТОВА И ЕГО ОКРЕСТНОСТЕЙ

\section{И.А. Яшков, А.С. Шешнёв, А.В. Иванов}

\author{
Саратовский государственный университет, \\ кафедра геоэкологии \\ E-mail: YashkovlA@mail.ru
}

На основе анализа литературы по изучению овражной эрозии на территории Саратова и его окрестностей отмечены основные методики и результаты исследований за более чем 130-летний период, а также направления современного изучения. Определен современный уровень изученности овражной эрозии территории.

Ключевые слова: овражная сеть, Саратов, исторический обзор, современное состояние.

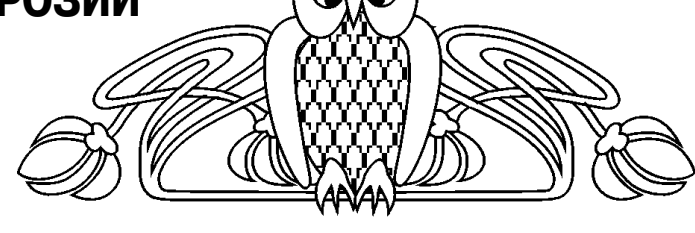

Condition of a Level of Scrutiny Gulling in Territory of Saratov and Vicinities

\section{I.A. Yashkov, A.S. Sheshnev, A.V. Ivanov}

On the basis of the analysis of the literature on studying gulling in territory of Saratov and vicinities the basic techniques and results of researches for more than 130-years period, and also directions of modern studying are noted. The modern level of a level of scrutiny gulling territories is certain.

Key words: ravine network, Saratov, history, modern status. 